\title{
Radium bromatum
}

National Cancer Institute

\section{Source}

National Cancer Institute. Radium bromatum. NCI Thesaurus. Code C158512.

An orally available homeopathic preparation with potential radioprotective activities. Upon administration, radium bromatum may reduce the occurrence of, and ameliorate the symptoms associated with radiation-induced dermatitis. 